Diversity of Research in Health Journal / Revue de la Diversité de la Recherche en Santé

Vol 1, pp 17-32, April 2017 - ISSN 2561-1666

\title{
Protecting the mental health of Ontario seniors
}

Ph. Montgomery, P. Nangia, Sh. Mossey, D. Pye,

Ph. Montgomery, RN, PhD

Professor, School of Nursing

Laurentian University

pmontgomery@laurentian.ca

P. Nangia, $\mathrm{PhD}$

Associate Professor, Department of Sociology

Laurentian University

pnangia@laurentian.ca

Sh. Mossey, RN, MScN

Assistant Professor, School of Nursing

Laurentian University

smossey@laurentian.ca

D. Pye, BScN

Student, School of Nursing

Laurentian University

dpye@laurentian.ca 
Diversity of Research in Health Journal / Revue de la Diversité de la Recherche en Santé

Vol 1, pp 17-32, April 2017

\begin{abstract}
Background: Chronic disease management has been the emphasis of research with elderly populations. Building upon this work, there is a need to examine protective practices and supports for the mental health of older adults. There are no Canadian empirical studies that examine those factors in relation to positive mental health.

Aim: This study identified associations between protective factors and self-rated mental health for senior, community-dwelling Ontarians.

Methods: A secondary analysis was undertaken to examine a subset of variables from the population-based Canadian Community Health Survey (2012) data. Statistical analysis correlated a range of extracted individual, social, and environmental variables for two major age groups of Ontarian seniors $(\mathrm{N}=6,121)$, those aged 65 to 79 , and those 80 years and older.

Results: Positive mental health was significantly associated with marital status, co-habilitation, income, perceived health, life stress, and health behaviours. This grouping of personal and social characteristics lost significance for positive mental health among seniors aged 80 years and older. Regardless of the seniors' age, flourishing mental health was predicated upon physical activity, positive self-rated physical health, and finally, limited life stress.

Conclusion: Based on provincial data, trends in self-rated positive mental health suggest that key factors ought to be integrated into the delivery of coordinated and interdisciplinary services to protect the mental health of seniors.
\end{abstract}

Keywords: Ontario seniors, mental health, secondary analysis

\title{
Résumé
}

Contexte: La gestion des maladies chroniques a mis l'accent sur la recherche auprès des populations âgées. Sur la base de ce travail, il est nécessaire d'examiner les pratiques de protection et de soutien pour la santé mentale des personnes âgées. Il n'existe pas d'études empiriques canadiennes qui examinent ces facteurs en rapport avec la santé mentale positive.

Objectif: Cette étude a identifié des associations entre les facteurs de protection et la santé mentale auto-évaluée pour les Ontariens seniors et vivant dans la communauté.

Méthodes: Une analyse secondaire a été entreprise pour examiner un sous-ensemble de variables provenant des données de l'Enquête sur la santé dans la collectivité (2012) basée sur la population. L'analyse statistique a corrélé une gamme de variables individuelles, sociales et environnementales extraites pour deux grands groupes d'âge des aînés d'Ontarie ( $N=6121)$, ceux âgés de 65 à 79 ans et ceux de 80 ans et plus.

Résultats: La santé mentale positive a été significativement associée à l'état matrimonial, à la cohabilitation, au revenu, à la santé perçue, au stress de la vie et aux comportements de santé. Ce groupe de caractéristiques personnelles et sociales a perdu de l'importance pour la santé mentale positive chez les personnes âgées de 80 ans et plus. Indépendamment de l'âge des aînés, la santé mentale prospère repose sur l'activité physique, la santé physique auto-évaluée positive et enfin le stress vital réduit.

Conclusion: Selon les données provinciales, les tendances de la santé mentale positive autoévaluée suggèrent que les facteurs clés devraient être intégrés à la prestation de services coordonnés et interdisciplinaires pour protéger la santé mentale des aînés.

Mots-clés: Les aînés en Ontario, santé mentale, analyse secondaire 
Diversity of Research in Health Journal / Revue de la Diversité de la Recherche en Santé

Vol 1, pp 17-32, April 2017

\section{Introduction}

In 2016, Statistics Canada reported that there were 5,780,900 Canadians 65 years of age and older. The majority of these individuals, as high as $90 \%$ (Statistics Canada, 2011) reside in non-institutional accommodations, within the community. Among this group of seniors, $83 \%$ report living with at least one chronic health diagnosis which has the potential to compromise their physical functioning (Chappell, 2008). Among Canadians, the frequency of antidepressant medication use has increased among both males and females identified using epidemiological data collected over a 15 year period (Simpson, Meadows, Frances, \& Patten, 2012). These authors found no appreciable change in the prevalence of major depressive episodes or self-rated mental health scores during this same period. Collectively, this work supports the complex nature of mental health among seniors, suggesting that it is more than the absence of physiological and psychological illness.

Despite debate in the literature, there are a number of often-cited constructs of mental health. Globally, the World Health Organization (WHO) describes mental health as a state of overall well-being characterized by recognition of ability to productively contribute to a community in the presence of normal life stresses (WHO, 2004). This definition is applicable to both individual and population measurements. Specific to seniors, this organization clarifies that perceptions of mental health by older adults are not substantially different than those held by younger people. The Mental Health Commission of Canada (2015), however, identifies that self-rated mental health among youth and adults is higher than seniors, thus raising a public health concern in Canada.

Keyes (2013) offers a detailed description of the attributes of positive mental health inclusive of three predominant and inter-related domains, emotional, social and psychological well-being. Specific to emotional well-being is general happiness, satisfaction with and interest in life. Social well-being involves acknowledgement of one's meaningful contribution to a community of respected others. Finally, psychological well-being encompasses general self-regard; perceived effectiveness in managing daily responsibilities; involved in fulfilling and supportive relationships; opportunities for growth; confidence in expressing one's own ideas; and self-determination. The specificity of this description has been used to guide national epidemiological surveys of mental health (Canadian Institute of Health Information, 2009).

More recently, Galderisi and colleagues (2015) presented a description of mental health to capture variability relative to context and culture. Their definition is as follows:

a dynamic state of internal equilibrium which enable individuals to use their abilities in harmony with universal values of society. Basic cognitive and social skills; ability to recognize, express and modulate one's own emotions, as well as empathize with others; flexibility and ability to cope with adverse life events and function in social roles; and harmonious relationship between body and mind represent important components of mental health which contribute, to varying degrees, to the state of internal equilibrium. (p. 231-232)

As such, mental health can be present in the context of the health challenges which often pervade the lives of seniors. Further, this definition acknowledges the importance of respect for self and others, an espoused value within Canadian society. For example, the Public Health Agency of Canada (2010) declares that mental health is the capacity of 
Diversity of Research in Health Journal / Revue de la Diversité de la Recherche en Santé

Vol 1, pp 17-32, April 2017

each Canadian to enjoy life and manage its challenges through his or her actions, thoughts and feelings. Further, this organization emphasizes the importance of a sense of emotional and spiritual well-being for mental health. From this perspective, culture, equity, social justice, interconnections and personal dignity must be respected.

The above definitions emphasize the subjective nature of mental health, with varying emphasis on its subcomponents including happiness, life-satisfaction, sense of belonging, self-determination. In the Canadian literature, indicators of mental health for populations of community-dwelling seniors include quality of life (Bassett, Bourbonnais \& McDowell, 2007; Michalos, Hubley, Zumbo \& Hemingway, 2001; Michalos, Ramsey, Eberts, \& Kahlke, 2012; Steptoe, de Oliveiera, \& Zaninotto, 2014), happiness (Newall, Chipperfield, Bailis, \& Stewart, 2013; Tamim, Mason, Shah, \& Dogra, 2012), social participation (Ramage-Morin, Margot, \& Laurent, 2010); sense of belonging (Kitchen, Williams, \& Chowhan, 2012; Mock, Fraser, Knutson \& Prier, 2010), well-being (Stanley \& Cheek, 2003), and life satisfaction (Bourque, Pushkar, Bonneville \& Béland, 2005).

Despite this growing body of evidence, there is a dearth of research specific to self-rated positive mental health. Such knowledge has the potential to guide proactive initiatives to protect and promote mental health of Canadian seniors. As identified by Keyes (2013),

If a nation wants better mental health, it must focus on positive mental health -promoting flourishing and protecting against its loss. Governments cannot promote mental health by solely reducing mental illness, and no amount of wishful thinking will make this fact disappear. (p. 25)

Within Canada, the protection and promotion of seniors' positive mental health is espoused as an important element within the continuum of mental health services (Mental Health Commission of Canada, 2011). Findings from a national community health survey indicate that nearly $70 \%$ of Canadian seniors reported their mental health as very good or excellent (Mental Health Commission of Canada, 2015). This statistic is indicative of social capital in which seniors with positive mental health have a greater capacity for functioning and less risk for illness over time (Chappell, 2008; Keyes, 2013; RamageMorin et al., Stones, Kozma, McNeil, \& Worobetz, 2011). Less is known about those variables that most contribute to self-reported mental health among Canadian seniors.

\section{Purpose}

This primary aim of this study was to determine factors protective of self-reported mental health among Ontario seniors. The two research questions were:

1. What factors are associated with varying levels of positive mental health?

2. What factors are predictive of positive mental health?

\section{Methods}

\section{Design}

A secondary analysis was conducted to examine the publicly available data reported in the Public Use Microdata File generated from the 2012 Canadian Community Health Survey (CCHS, Statistics Canada, 2012). This national survey is a main data 
Diversity of Research in Health Journal / Revue de la Diversité de la Recherche en Santé

Vol 1, pp 17-32, April 2017

source for health surveillance and population health research in Canada. The CCHS targets the Canadian population aged 12 years or older. The publicly reported data are intended to provide a broad range of accessible and reliable information on health and well-being, factors that affect health, health system utilization, as well as a standard set of demographic and socioeconomic characteristics.

\section{Setting and Sample}

In the national survey, a multi-staged probability sampling strategy was used for selection of geographical areas, households, and respondents. Statistics Canada (2012) reported the exclusions from the survey as follows:

persons living on reserves and other Aboriginal settlements in the provinces; fulltime members of the Canadian Forces; the institutionalized population and persons living in the Quebec health regions of Région du Nunavik and Région des Terres-Cries-de-la-Baie-James. In Nunavut, the coverage is limited to the ten largest [communities] which represents about $70 \%$ of the Nunavut population.

The total survey sample was 61,707 Canadians aged 12 years and older living in private dwellings across ten provinces and three territories. Within this sample, was a sub-sample of 6,121 seniors aged 65 years or older, residing in non-institutional settings within Ontario. This sample is representative of 2.29 million seniors in Ontario.

\section{Data extraction}

The data reported in the CCHS addressed multiple dimensions of mental health. To identify data about the factors that protect mental health among seniors, an extraction template was developed using a recent Canadian guideline of best practices in seniors' mental health promotion (Centre for Addiction and Mental Health, 2010). The template identified individual (age, sex, physical activity, independence with activities of daily living, coping skills), family/social (marital status, living arrangements, household size), life events/situations (alcohol use, smoking, general physical health, physical activity index, perceived life stress, food security, personal income, household income), and community/cultural factors (geographic location, involvement in one's community) potentially protective of mental health.

In the survey, mental health in the past month was measured by Keyes' (2002) instrument of 14-items divided into emotional, social, and psychological well-being (Table 1). Seniors ranked the frequency of each item on a six-point Likert scale from "everyday" to "never." Data were extracted in accordance with the three classifications of mental health, languishing, moderate, and flourishing. Seniors with languishing mental health "never" or "once or twice a month" reported at least seven items. Seniors with moderate mental health "once a week" or "two or three times a week" reported at least seven items. Finally, seniors with flourishing mental health, reported experiencing seven or more items, at least one of which was associated with emotional wellbeing, "almost every day" or "every day." The extracted data were used to provide weighted estimates. 
Diversity of Research in Health Journal / Revue de la Diversité de la Recherche en Santé

Vol 1, pp 17-32, April 2017

Table 1 The Mental Health Continuum

Domains of Item

mental health

$\begin{array}{ll}\text { Emotional } & \text { 1. Happy } \\ \text { well-being } & \text { 2. Interested in life } \\ & \text { 3. Satisfied with one's life }\end{array}$

Social 4. That you had something important to contribute to society

well-being 5. That you belonged to a community

6. That our society is becoming a better place for people like you

7. That people are basically good

8. That the way our society works made sense to you

Psychological 9. That you like most parts of your personality

well-being 10 . Good at managing the responsibilities of your daily life

11. That you had warm and trusting relationships with others

12. That you had experiences that challenged you to grow and become a better person

13. Confident to think or express your own ideas and opinions

14. That your life has a sense of direction or meaning to it

\section{Data analysis}

Extracted data for Ontario seniors were analyzed as follows. To determine those factors associated with varying levels of positive mental health, data were initially organized into three groups: all seniors (aged 65 and over), younger seniors (aged 65 to 79 years), and older seniors (aged 80 years and over). Then the three levels of mental health, languishing, moderate, and flourishing were calculated for each age group. Descriptive statistics were used to analyze each variable protective of mental health for each age group and significance $(p<05)$. Chi-square and Fisher's exact tests were used to identify significant differences or associations using actual sample values. To determine factors predictive of positive mental health, logistic regression was used. Three separate models, predictive of positive mental health were developed, one for each age grouping.

\section{Results}

The presentation of results, relevant protective factors for self-rated mental health among Ontario seniors, are organized according to the two research questions. First those factors associated with varying levels of positive mental health are described. Secondly, 
Diversity of Research in Health Journal / Revue de la Diversité de la Recherche en Santé

Vol 1, pp 17-32, April 2017

the logistic regression results are presented to detail the impact of health protective factors on flourishing mental health.

\section{Factors associated with positive mental health}

Based on analysis of extracted data from the 2012 CCHS, it was determined that the majority of community-dwelling Ontario seniors (81\%) experience flourishing mental health, a higher proportion compared to seniors in Canada (79\%). In comparison, two percent of the seniors were categorized as having languishing mental health in Ontario as compared to one percent in Canada. With age there was deterioration in flourishing mental health. More than $80 \%$ of the seniors below 80 years of age in Ontario had flourishing mental health; this proportion reduced significantly to $73 \%$ for those seniors 80 years of age or older. Though languishing mental health did not show a significant change with age, the proportion of seniors with moderate mental health increased substantially in the age group 80 and above (Figure 1).

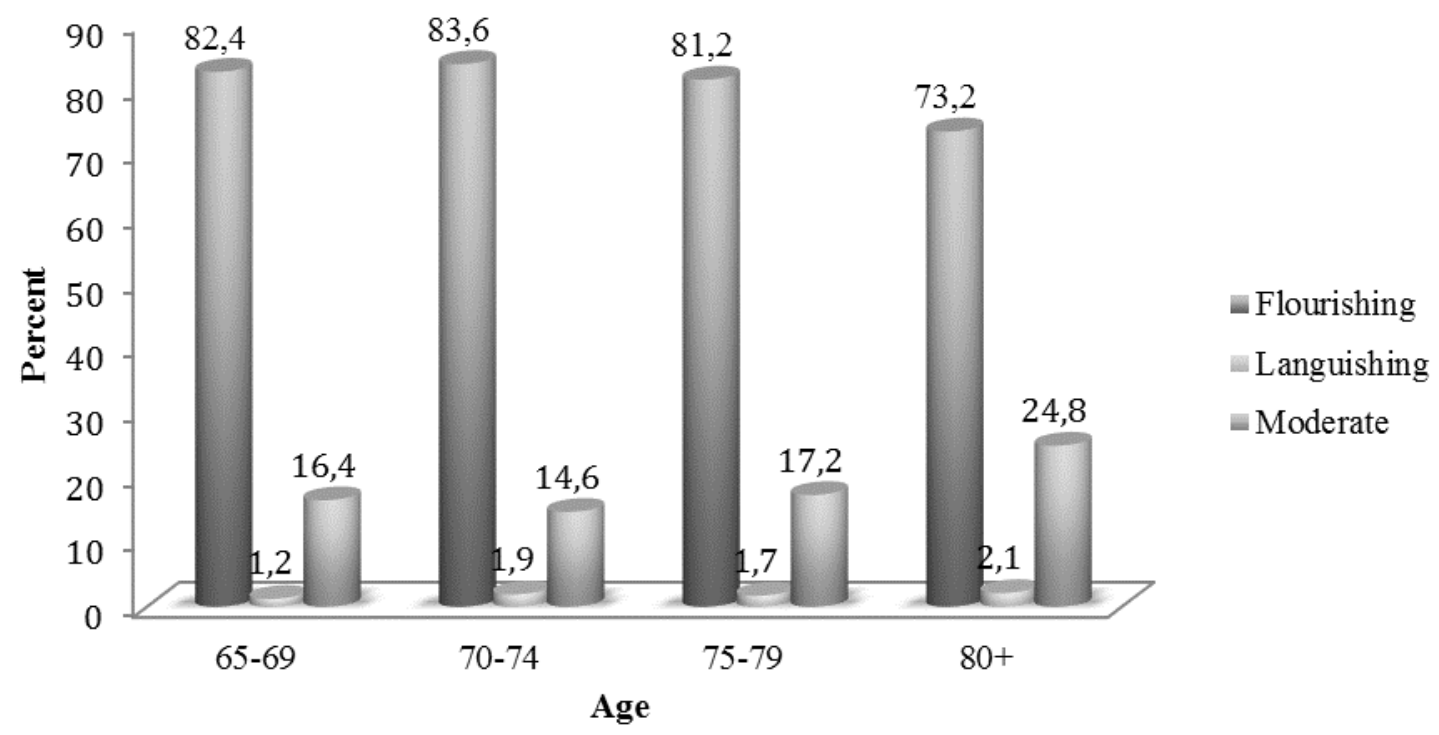

Figure 1. Levels of positive mental health in Ontario by age groups Source: CCHS (Statistics Canada, 2012).

Given the small proportion of seniors that were categorized as having languishing mental health, data for this group was combined with those classified as having moderate mental health in subsequent analysis.

The weighted percentages of positive mental health by various individual and social characteristics are presented in Table 2. There is no significant difference in the levels of positive mental health of seniors by geographical health region, sex, and number of children (12 years or younger) in the household. However, having two or more persons in the household is associated with higher percentage of seniors having flourishing mental health. A higher proportion of those who are married or live common-law had flourishing mental health compared to those seniors who are widowed, divorced, 
separated, or never married. Living alone or with non-family members is less likely to contribute to flourishing mental health. Personal and household income had a strong association with positive mental health. A higher proportion of those who have higher income experienced flourishing mental health. Perceived physical health and life stress had a strong association with positive mental health. A higher proportion of those who have excellent or very good physical health have flourishing mental health. With increased life stress, the proportion of those with flourishing mental health declines. Marital status, living arrangements, household size, number of persons 12 years of age or less in the household, total household income, and total personal income lose their statistical significance relative to levels of mental health among the older seniors. For older seniors, flourishing mental health was exclusively associated with higher level of self-rated general health and limited stress.

Table 3 shows that health behaviours such as physical activity, alcohol intake, and smoking are found to be associated with mental health. Nearly half of those seniors who are categorized as having flourishing mental health report being active or moderately active. More than two-thirds of those who have languishing/moderate mental health, however, are inactive. A large majority of seniors reported that they do not smoke. Nearly $8 \%$ of those with flourishing mental health smoke daily compared to $11 \%$ with languishing/moderate mental health. The majority of those with flourishing mental health (56\%) drink on a regular basis, but less than half of those with languishing/moderate mental health (45\%) drink regularly. Independence in accomplishing daily tasks and food security, the assurance of having enough good quality food, are associated with positive mental health. Inability to perform routine tasks and dependence on others for essential things like preparing meals, getting to appointments, moving about in the house, personal care, domestic chores and taking care of finances affects mental health in a negative way. Less than one-fifth of those who have flourishing mental health need help for various tasks, whereas nearly one-third of those with languishing/moderate mental health need help from others for at least one routine task. Though most of the seniors feel food secure, a higher proportion of those with languishing mental health experience moderate to severe food insecurity. Particular to the group of older seniors, aged 80 years and older, the two health behaviours that did not have a significant association with positive mental health are alcohol intake and smoking. 
Diversity of Research in Health Journal / Revue de la Diversité de la Recherche en Santé

Vol 1, pp 17-32, April 2017

Table 2 Positive Mental Health of Ontario Seniors (Weighted \%) by Individual and Social Characteristics

\begin{tabular}{|c|c|c|c|c|c|c|c|c|c|}
\hline \multirow[b]{2}{*}{$\begin{array}{l}\text { Individual and Social } \\
\text { Characteristics }\end{array}$} & \multicolumn{3}{|c|}{ All seniors (age 65+) } & \multicolumn{3}{|c|}{ Younger seniors (age 65-79) } & \multicolumn{3}{|c|}{ Older seniors (age $80+$ ) } \\
\hline & Flourishing & $\begin{array}{l}\text { Languishing/ } \\
\text { Moderate }\end{array}$ & $\begin{array}{c}\text { Chi-square } \\
p\end{array}$ & Flourishing & $\begin{array}{l}\text { Languishing/ } \\
\text { Moderate }\end{array}$ & $\begin{array}{c}\text { Chi-square } \\
P\end{array}$ & Flourishing & $\begin{array}{l}\text { Languishing/ } \\
\text { Moderate }\end{array}$ & $\begin{array}{c}\text { Chi-square } \\
p\end{array}$ \\
\hline All Ontario & 80.6 & 19.4 & & 82.5 & 17.5 & & 73.2 & 26.8 & \\
\hline Northern & 83.0 & 17.0 & .212 & 83.2 & 16.8 & .708 & 82.1 & 17.9 & .106 \\
\hline Southern & 80.4 & 19.6 & & 82.4 & 17.6 & & 72.5 & 27.5 & \\
\hline \multicolumn{10}{|l|}{ Sex } \\
\hline Male & 79.7 & 20.3 & .58 & 81.2 & 18.8 & .42 & 73.2 & 26.8 & .643 \\
\hline Female & 81.3 & 18.7 & & 83.5 & 16.5 & & 73.1 & 26.9 & \\
\hline \multicolumn{10}{|l|}{ Marital status } \\
\hline Married & 82.8 & 17.2 & $<.001$ & 84.2 & 15.8 & $<.001$ & 74.1 & 25.9 & $.297 *$ \\
\hline Common-law & 85.4 & 14.6 & & 84.6 & 15.4 & & 100.0 & 0.0 & \\
\hline Widowed/separated & 75.9 & 24.1 & & 78.4 & 21.6 & & 71.4 & 28.6 & \\
\hline Never married & 76.1 & 23.9 & & 75.0 & 25.0 & & 81.7 & 18.3 & \\
\hline \multicolumn{10}{|l|}{ Living arrangements } \\
\hline Unattached alone & 76.8 & 23.2 & $<.001$ & 78.4 & 21.6 & $<.001$ & 73.9 & 26.1 & $.578 *$ \\
\hline Unattached other & 68.4 & 31.6 & & 76.7 & 23.3 & & 42.5 & 57.1 & \\
\hline Spouse/partner & 83.2 & 16.8 & & 85.1 & 14.9 & & 71.5 & 28.5 & \\
\hline Parent/spouse/child & 87.6 & 12.4 & & 87.1 & 12.9 & & 90.3 & 9.7 & \\
\hline Parent child & 73.3 & 26.7 & & 75.4 & 24.6 & & 68.6 & 31.4 & \\
\hline Other & 76.1 & 23.9 & & 74.7 & 25.3 & & 85.5 & 14.5 & \\
\hline \multicolumn{10}{|l|}{ Household size } \\
\hline Senior only & 76.8 & 23.2 & $<.001$ & 78.4 & 21.6 & $<.001$ & 73.9 & 26.1 & .526 \\
\hline Senior plus 1 & 82.1 & 17.9 & & 84.5 & 15.5 & & 69.2 & 30.8 & \\
\hline Senior plus $\geq 2$ & 80.6 & 19.4 & & 79.3 & 20.7 & & 88.5 & 11.5 & \\
\hline \multicolumn{10}{|c|}{ Number of persons age $<=12$ years in household } \\
\hline None & 80.6 & 19.4 & .845 & 82.6 & 17.4 & .834 & 73.1 & 26.9 & $1.0 *$ \\
\hline 1 or more & 78.6 & 21.4 & & 78.3 & 21.7 & & 100.0 & 0.0 & \\
\hline
\end{tabular}


Diversity of Research in Health Journal / Revue de la Diversité de la Recherche en Santé

Vol 1, pp 17-32, April 2017

Table 2 continued

\begin{tabular}{|c|c|c|c|c|c|c|c|c|c|}
\hline \multirow[b]{2}{*}{$\begin{array}{c}\text { Individual and social } \\
\text { characteristics }\end{array}$} & \multicolumn{3}{|c|}{ All seniors (age 65+) } & \multicolumn{3}{|c|}{ Younger seniors (age 65-79) } & \multicolumn{3}{|c|}{ Older seniors (age $80+$ ) } \\
\hline & Flourishing & $\begin{array}{l}\text { Languishing/ } \\
\text { Moderate }\end{array}$ & $\begin{array}{c}\text { Chi-square } \\
p \\
\end{array}$ & Flourishing & $\begin{array}{l}\text { Languishing/ } \\
\text { Moderate }\end{array}$ & $\begin{array}{c}\text { Chi-square } \\
p\end{array}$ & Flourishing & $\begin{array}{l}\text { Languishing/ } \\
\text { Moderate }\end{array}$ & $\begin{array}{c}\text { Chi-square } \\
p\end{array}$ \\
\hline \multicolumn{10}{|c|}{ Total household income from all sources } \\
\hline No or $<20,000$ & 70.3 & 29.7 & $<.001$ & 72.0 & 28.0 & $<.001$ & 66.1 & 33.9 & .085 \\
\hline $20,000-39,999$ & 78.1 & 21.9 & & 79.9 & 20.1 & & 73.2 & 26.8 & \\
\hline $40,000-59,999$ & 79.2 & 20.8 & & 80.5 & 19.5 & & 73.9 & 26.1 & \\
\hline $60,000+$ & 86.7 & 13.3 & & 88.3 & 11.7 & & 76.7 & 23.3 & \\
\hline \multicolumn{10}{|c|}{ Total personal income from all sources } \\
\hline No or $<20,000$ & 72.4 & 27.6 & $<.001$ & 73.6 & 26.4 & $<.001$ & 68.1 & 31.9 & .153 \\
\hline $20,000-39,999$ & 80.0 & 20.0 & & 82.4 & 17.6 & & 73.3 & 26.7 & \\
\hline $40,000-59,999$ & 83.9 & 16.1 & & 86.0 & 14.0 & & 74.7 & 25.3 & \\
\hline $60,000+$ & 91.0 & 9.0 & & 92.9 & 7.1 & & 80.9 & 19.1 & \\
\hline \multicolumn{10}{|l|}{ Self-perceived health } \\
\hline Excellent & 93.1 & 6.9 & $<.001$ & 93.5 & 6.5 & $<.001$ & 90.9 & 9.1 & $<.001$ \\
\hline Very good & 86.6 & 13.4 & & 88.7 & 11.3 & & 76.0 & 24.0 & \\
\hline Good & 79.4 & 20.6 & & 79.3 & 20.7 & & 79.8 & 20.2 & \\
\hline Fair & 65.6 & 34.4 & & 66.6 & 33.4 & & 62.8 & 37.2 & \\
\hline Poor & 56.2 & 43.8 & & 62.5 & 37.5 & & 45.2 & 54.8 & \\
\hline \multicolumn{10}{|l|}{ Perceived life stress } \\
\hline Not at all & 84.7 & 15.3 & $<.001$ & 86.9 & 13.1 & $<.001$ & 77.6 & 22.4 & $.002 *$ \\
\hline Not very & 84.5 & 15.5 & & 86.6 & 13.4 & & 75.5 & 24.5 & \\
\hline A bit & 78.0 & 22.0 & & 80.0 & 20.0 & & 69.9 & 30.1 & \\
\hline Quite a bit & 70.6 & 29.4 & & 71.3 & 28.7 & & 67.7 & 32.3 & \\
\hline Extreme & 67.5 & 32.5 & & 70.5 & 29.5 & & 58.7 & 41.3 & \\
\hline $\mathrm{N} * *$ & 4370 & 1005 & & 3373 & 698 & & 997 & 307 & \\
\hline
\end{tabular}

* Fisher's Exact Test

$* * \mathrm{~N}$ refers to community dwelling Ontario Seniors. Information on positive mental health is missing for 438 seniors aged 65-79 and 308 seniors age $80+$

Source: CCHS (Statistics Canada, 2012). 
Diversity of Research in Health Journal / Revue de la Diversité de la Recherche en Santé

Vol 1, pp 17-32, April 2017

Table 3 Positive Mental Health of Ontario Seniors (Weighted \%) by Health Behaviors and Life Events

\begin{tabular}{|c|c|c|c|c|c|c|c|c|c|}
\hline \multirow[b]{2}{*}{$\begin{array}{l}\text { Health behaviors } \\
\text { and life events }\end{array}$} & \multicolumn{3}{|c|}{ All seniors (age 65+) } & \multicolumn{3}{|c|}{ Younger seniors (age 65-79) } & \multicolumn{3}{|c|}{ Older seniors (age 80+) } \\
\hline & Flourishing & $\begin{array}{l}\text { Languishing/ } \\
\text { Moderate }\end{array}$ & $\begin{array}{c}\text { Chi-square } \\
p\end{array}$ & Flourishing & $\begin{array}{l}\text { Languishing/ } \\
\text { Moderate }\end{array}$ & $\begin{array}{c}\text { Chi-square } \\
P\end{array}$ & Flourishing & $\begin{array}{l}\text { Languishing/ } \\
\text { Moderate }\end{array}$ & $\begin{array}{c}\text { Chi-square } \\
p\end{array}$ \\
\hline \multicolumn{10}{|l|}{ Physical activity index } \\
\hline Active & 23.2 & 12.4 & $<.001$ & 24.8 & 15.9 & $<.001$ & 16.1 & 3.6 & $<.001$ \\
\hline Moderate active & 25.3 & 19.7 & & 26.1 & 20.9 & & 21.7 & 16.4 & \\
\hline Inactive & 51.5 & 67.9 & & 49.1 & 63.2 & & 62.2 & 80.0 & \\
\hline \multicolumn{10}{|c|}{ Type of drinker (last 12 months) } \\
\hline Regular drinker & 55.5 & 45.2 & $<.001$ & 58.8 & 48.3 & $<.001$ & 40.8 & 37.1 & .454 \\
\hline Occasional drinker & 15.7 & 18.3 & & 14.5 & 16.0 & & 20.6 & 24.4 & \\
\hline No drinking & 28.9 & 36.5 & & 26.7 & 35.7 & & 38.6 & 38.5 & \\
\hline \multicolumn{10}{|l|}{ Type of smoker } \\
\hline Daily & 7.9 & 11.4 & .004 & 8.7 & 13.8 & .001 & 4.3 & 5.4 & $.099 *$ \\
\hline Occasionally & 1.3 & 2.5 & & 1.5 & 1.6 & & 0.6 & 4.9 & \\
\hline Not at all & 90.8 & 86.1 & & 89.8 & 84.6 & & 95.1 & 89.7 & \\
\hline \multicolumn{10}{|l|}{ Needs help } \\
\hline Preparing meals & 5.2 & 13.5 & $<.001$ & 3.5 & 10.1 & $<.001$ & 12.7 & 22.2 & $<.001$ \\
\hline Get to appointments & 11.8 & 19.4 & $<.001$ & 6.9 & 13.1 & $<.001$ & 33.5 & 35.7 & $<.001$ \\
\hline Doing housework & 12.5 & 22.3 & $<.001$ & 8.3 & 17.2 & $<.001$ & 31.0 & 35.5 & $<.001$ \\
\hline Personal care & 3.2 & 10.1 & $<.001$ & 1.9 & 7.0 & $<.001$ & 8.9 & 17.9 & $<.001$ \\
\hline Mobility in house & 2.2 & 6.6 & $<.001$ & 1.3 & 4.2 & $<.001$ & 6.0 & 12.9 & .001 \\
\hline Finances & 4.7 & 8.6 & $<.001$ & 2.7 & 6.8 & $<.001$ & 13.3 & 13.3 & .004 \\
\hline Completing tasks & 17.8 & 32.4 & $<.001$ & 11.8 & 25.4 & $<.001$ & 44.2 & 50.3 & $<.001$ \\
\hline \multicolumn{10}{|c|}{ Household food security status } \\
\hline Secure & 98.6 & 96.3 & $<.001 *$ & 98.3 & 96.3 & $<.001 *$ & 99.5 & 96.0 & $.001 *$ \\
\hline Moderate insecure & 1.3 & 3.1 & & 1.5 & 2.9 & & 0.5 & 3.8 & \\
\hline Severe insecure & 0.2 & 0.6 & & 0.2 & 0.8 & & 0.0 & 0.2 & \\
\hline $\mathrm{N}$ & 4370 & 1005 & & 3373 & 698 & & 997 & 307 & \\
\hline
\end{tabular}

* Fisher's Exact Test

Source: CCHS (Statistics Canada, 2012). 
Diversity of Research in Health Journal / Revue de la Diversité de la Recherche en Santé

Vol 1, pp 17-32, April 2017

\section{Factors predictive of positive mental health}

Each of the three models, predictive of flourishing mental health, are specific to one of the three age groups of seniors (Table 4). Multiple independent variables were initially selected and subsequently dropped as they did not have a significant effect on flourishing mental health and reduced the R-square value. A total of five independent variables remained following analysis and included physical activity, need for assistance with daily activities, household size, self-perceived health and life stress. For the latter two variables the researchers pooled the reference categories to increase cell frequencies.

Table 4 Prediction of Positive Mental Health of Ontario Seniors

\begin{tabular}{|c|c|c|c|c|c|c|}
\hline & \multicolumn{2}{|c|}{$\begin{array}{l}\text { All seniors } \\
\text { (age } 65+\text { ) }\end{array}$} & \multicolumn{2}{|c|}{$\begin{array}{l}\text { Younger seniors } \\
\text { (age 65-79) }\end{array}$} & \multicolumn{2}{|c|}{$\begin{array}{l}\text { Older seniors } \\
\text { (age } 80+\text { ) }\end{array}$} \\
\hline & $\begin{array}{l}\text { Odds } \\
\text { ratio }\end{array}$ & $\begin{array}{l}\text { Confidenc } \\
\text { e Interval }\end{array}$ & $\begin{array}{l}\text { Odds } \\
\text { ratio }\end{array}$ & $\begin{array}{l}\text { Confidenc } \\
\text { e Interval }\end{array}$ & $\begin{array}{l}\text { Odds } \\
\text { ratio }\end{array}$ & $\begin{array}{l}\text { Confidence } \\
\text { Interval }\end{array}$ \\
\hline \multicolumn{7}{|c|}{ Physical activity index (Reference category $=$ Active $)$} \\
\hline Moderate active & .95 & $.74-1.21$ & .99 & $.76-1.30$ & .80 & $.46-1.39$ \\
\hline Inactive & $.66 * * *$ & $.53-.81$ & $.69 * *$ & $.55-.88$ & $.58^{*}$ & $.37-.93$ \\
\hline \multicolumn{7}{|c|}{ Help needed for tasks (Reference category $=$ Yes) } \\
\hline No & $1.33 * *$ & $1.12-1.57$ & 1.22 & $.98-1.52$ & $1.43^{*}$ & $1.08-1.89$ \\
\hline \multicolumn{7}{|c|}{ Household size (Reference category $=1$ ) } \\
\hline Senior plus 1 & $\begin{array}{l}1.42 * * \\
*\end{array}$ & $1.23-1.65$ & $\begin{array}{l}1.51 * * \\
*\end{array}$ & $1.27-1.80$ & 1.04 & $.78-1.39$ \\
\hline Senior plus $\geq 2$ & 1.24 & $.86-1.80$ & 1.14 & $.75-1.72$ & 1.67 & $.72-3.89$ \\
\hline \multicolumn{7}{|c|}{ Perceived self-health (Reference category $=$ Excellent/ Very good) } \\
\hline Good & $.61 * * *$ & $.51-.72$ & $.52 * * *$ & $.42-.64$ & .91 & $.65-1.27$ \\
\hline Fair/Poor & $.43 * * *$ & $.35-.52$ & $.39 * * *$ & $.30-.49$ & $.54 * *$ & $.38-.77$ \\
\hline \multicolumn{7}{|c|}{ Perceived life stress (Reference category $=$ Not at all $/$ Not very) } \\
\hline A bit & $.71 * * *$ & $.60-.83$ & $.67 * * *$ & $.55-.81$ & .79 & $.58-1.06$ \\
\hline Quite a bit/extreme & $.44 * * *$ & $.35-.54$ & $.40 * * *$ & $.31-.51$ & $.55 * *$ & $.35-.85$ \\
\hline
\end{tabular}

Source: CCHS (Statistics Canada, 2012).

The first model, involving 5,315 seniors, aged 65 years and older, predicted $82 \%$ of them correctly. It produced Nagelkerke R-square value of .100. In comparison to physically active seniors, those who were classified as "inactive" were less likely to have flourishing mental health (Odds Ratio $[\mathrm{OR}]=0.66$ Confidence Interval $[\mathrm{CI}] 0.53$ to 0.81 ). Seniors who did not need any help with activities of daily living were more likely to have flourishing mental health compared to those who needed assistance $(\mathrm{OR}=1.33$ CI 1.12 to 1.57). All seniors living with one other person in their home were more likely to have flourishing mental health compared to those who lived alone (OR $=1.42 \mathrm{CI} 1.23$ to 1.65). Household sizes with three or more persons did not yield a statistically significance difference from the reference category of living alone. Higher perceived health was a predictor of flourishing mental health. Further, increased levels of perceived life stress predicted decreased flourishing mental health ( $\mathrm{OR}=0.44$, CI 0.35 to 0.54). 
Diversity of Research in Health Journal / Revue de la Diversité de la Recherche en Santé Vol 1, pp 17-32, April 2017

The second model, exclusive to 4,034 younger seniors (age 65 to 79), predicted $83.1 \%$ of them correctly with Nagelkerke R-square of .109. As in the first model, all of the above variables demonstrated a similar effect on flourishing mental health with one exception. There was no significant difference between those who needed or did not need assistance for activities of daily living.

The third model, involving 1,281 older seniors (age 80+), predicted $77 \%$ of them correctly. The Nagelkerke R-square was 0.07 . Flourishing mental health was less likely with physical inactivity in comparison to activity ( $\mathrm{OR}=0.58$, CI 0.37 to 0.93 ). Those who did not require help with daily activities were significantly more likely to have flourishing mental health compared to those who needed help ( $\mathrm{OR}=1.43$, CI 1.08 to 1.89). Household size did not yield a statistically significant association with flourishing mental health. As compared to those who perceived their health status as "excellent" and "very good, " older seniors in the lowest category of perceived health were less likely to have flourishing mental health $(\mathrm{OR}=0.54$, CI 0.38 to 0.77). As well, older seniors who perceived high levels of life stress had a decreased odds of flourishing mental health compared to those with no or minimal stress $(\mathrm{OR}=0.55$, CI 0.35 to 0.85$)$.

\section{Discussion and Conclusion}

This study examined the nature of positive mental health among communitydwelling Ontario seniors based on a secondary analysis of publicly available data from the CCHS (Statistics Canada, 2012). The results concur with other study findings about the prevalence of positive mental health among aging populations (Canadian Institute of Health Information, 2009; Public Health Agency of Canada, 2010). Similar to these other studies, positive mental health was associated with being married, having adequate finances, being physically active and functioning. No geographic differences in selfreported mental health were identified within Ontario. Further, positive mental health was comparable between men and women.

The presence of age-specific differences among this study's sample suggests that generalizations about all seniors' mental health are problematic. In order to protect positive mental health for successful aging, consideration of age-specificity is important. The study results show different associations between positive mental health and individual and social factors relative to age grouping. Such findings support the heterogeneity of the elderly population, a focus that requires service providers to understand varied life courses influenced by context (Bülow \& Söderquvist, 2014; Martinson \& Berridge, 2015). Members of the interdisciplinary team who offer services to support the positive mental health of seniors are best positioned with an understanding of age-specific differences.

For the oldest of the old, age 80 and greater, self-rating of overall general health was shown to have a direct role in determining self-reported mental health. As identified by Bassett et al. (2007), adapting to challenges and stressors resultant from physical illness has been found to be important for keeping well. As such, mental health status is best determined concurrently with assessment of perceived physical well-being in the older senior population. The coordination of interdisciplinary service providers has the potential to promote holistic services for the positive mental health of this speciality population, a source of social capital (Steptoe, Deaton, \& Stone, 2015). Further, perception of life stress had a direct relationship with flourishing mental health in this 
Diversity of Research in Health Journal / Revue de la Diversité de la Recherche en Santé Vol 1, pp 17-32, April 2017

population of older seniors. Stress management programs, inclusive of physical activity and the development of coping skills, targeted to adults aged 80 and older offers protection of positive mental health. Given the prevalence of chronic health challenges in this population, ability to independently manage activities of daily living and ensure access to adequate and quality food can be compromised. Pragmatic services to address these challenges have the potential to safeguard physical as well as mental well-being.

In summary, this study offers evidence to inform practices, service delivery, and policy for positive mental health, an element of successful aging among Ontario seniors. A limitation of this study was that not all of the conceptual elements of positive mental health were publically available. Overall, positive mental health is protected through functional ability, social connectedness, coping with life challenges, and keeping physically active.

\section{Acknowledgement}

The data for this study were obtained from Statistics Canada in the form of Public Use Microdata Files. The results and views presented in this paper are those of authors and not of the Statistics Canada.

\section{References}

Bassett, R., Bourbonnais, V., \& McDowell, I. (2007). Living long and keeping well: Elderly Canadians account for success in aging. Canadian Journal of Aging, 26(2), 113-126. doi:10.3138/cja.26.2.113

Bourque, P., Pushkar, D., Bonneville, L., \& Béland, F. (2005). Contextual effects on life satisfaction of older men and women. Canadian Journal of Aging, 24(1), 31-44. doi:10.1353/cja.2005.0001

Bülow, M. H., \& Söderquvist, T. (2014). Successful aging: A historical overview and critical analysis of a successful concept. Journal of Aging Studies, 31, 139-149. doi: 0.1016/j.jaging.2014.08.009

Canadian Institute of Health Information. (2009). Improving the health of Canadians: Exploring positive mental health (ISBN 978-1-55465-489-5). Ottawa: Author. Retrieved from the CIHI website: https://www.cihi.ca/en/improving_health_canadians_en.pdf

Centre for Addiction and Mental Health (2010). Best practice guidelines for mental health promotion programs: Older adults 55+( ISBN 978-1-77052-537-5).

Toronto, ON: Author. Retrieved from the CAMH website: https://www.porticonetwork.ca/documents/81358/128451/Older+Adults+55\%2B/ d27d7310-ba6c-4fe8-91d1-1d9e60c9ce72

Chappell, N. L. (2008). Aging and mental health. Social Work in Mental Health, 7(1-3), 122-138. doi:10.1080/15332980802072454

Galderisi, S., Heinz., A., Kastrup, M., Beezhold, J., \& Sartorius, N. (2015). Toward a new definition of mental health. World Psychiatry, 14(2), 231-253. doi:10.1002/wps.20231.

Keyes, C. L. M. (2002). The mental health continuum: from languishing to flourishing in life. Journal of Health and Social Behavior, 43, 207-222. doi:10.1037/a0013954 
Diversity of Research in Health Journal / Revue de la Diversité de la Recherche en Santé Vol 1, pp 17-32, April 2017

Keyes, C., L., M. (2013). Promoting and protecting positive mental health: Early and often throughout the lifespan. In C. L. M. Keyes (Ed.), Mental well-being: international contributions to the study of positive mental health (pp. 3-28). Dordrecht, Netherlands: Springer.

Kitchen, P., Williams, A., \& Chowhan, J. (2012). Sense of community belonging and health in Canada: A Regional analysis. Social Indicators Research, 107(1), 103126. doi:10.1007/sl 1205-011-9830-9

Martinson, M. \& Berridge, C. (2015). Successful aging and its discontents: A systematic review of the social gerontology literature. The Gerontologist, 55(1), 58-69. doi:10.1093/geront/gnu037

Mental Health Commission of Canada. (2015). Informing the future: Mental health indicators for Canada (ISBN: 978-0-9880506-8-6). Ottawa, ON: Author. Retrieved from the MHCC website: http://www.mentalhealthcommission.ca

Mental Health Commission of Canada. (2011). Guidelines for comprehensive mental health services for older adults. Calgary, AB: Author. Retrieved from the MHCC website: http://www.mentalhealthcommission.ca

Michalos, A. C., Hubley, A. M., Zumbo, B. D., \& Hemingway, D. (2001). Heath and other aspects of the quality of life of older people. Social Indicators Research, 54, 239-274. doi:10.1023/A:1011045307643

Michalos, A., C., Ramsey, D., Eberts, D., \& Kahlke, P. M. (2012). Good health is not the same as a good life: survey results from Brandon, Manitoba. Social Indicators Research, 107, 201-234. doi:10.1007/s11205-011-9854-1

Mock, S. E., Fraser, C., Knutson, S., \& Prier, A. (2010). Physical leisure participation and the well-being of adults with rheumatoid arthritis: the role of sense of belonging. Activities, Adaptation \& Aging, 34(4), 292-302. doi:

$10.1080 / 01924788.2010 .523870$

Newall, N. E. G., Chipperfield, J. G., Bailis, D., S., \& Stewart, T. L. (2013). Consequences of loneliness on physical activity and mortality in older adults and the power of positive emotions. Health Psychology, 32(8), 921-924. doi: $10.1037 / \mathrm{a} 0029413$

Public Health Agency of Canada. (2010). The Chief Public Health Officer's report on the state of public health in Canada, 2010: Growing older - adding life to years (ISBN: 978-1-100-16677-3). Ottawa, ON: Author. Retrieved from www.phacaspc.gc.ca/cphorsphc-respcacsp/2010/fr-rc/.../cpho_report_2010_e.pdf

Ramage-Morin, P. L., Margot, S., \& Laurent, M. (2010). Health-promoting factors and good health among canadians in mid- to late life. Health Reports, 21(3), 45-53. Retrieved from https://www.ncbi.nlm.nih.gov/pubmed/20973433

Simpson, K. R. S., Meadows, G. N., Frances, A. J., \& Patten, S. B. (2012). Is mental health in the canadian population changing over time? Canadian Journal of Psychiatry, 57(5), 324-331. doi:10.1177/070674371205700508

Stanley, M., \& Cheek, J. (2003). Well-being and older people: a review of the literature. Canadian Journal of Occupational Therapy, 70(1), 51-59. doi: $10.1177 / 000841740307000107$

Statistics Canada. 2012. Canadian Community Health Survey - Annual Component. Retrieved from 
Diversity of Research in Health Journal / Revue de la Diversité de la Recherche en Santé

Vol 1, pp 17-32, April 2017

http://www23.statcan.gc.ca/imdb/p2SV.pl?Function=getSurvey\&Id=135927.

Annualy.

Statistics Canada. 2011. Living arrangements of seniors. Statics Canada Catalogue no. 98-312-X2011003. Ottawa, Ontario. September 2012.

https://www12.statcan.gc.ca/census-recensement/2011/as-sa/98-312-x/98-312x2011003_4-eng.cfm

Steptoe, A. Deaton, A., \& Stone, A. (2015). Subjective wellbeing, health, and ageing. The Lancet, 385(9968), 640-648. doi:10.1016/S0140-6736(13)61489-0

Steptoe, A., de Oliveira, C., Demakakos, P., \& Zaninotto, P. (2014). Enjoyment of life and declining physical function at older ages: a longitudinal cohort study.

Canadian Medical Association Journal, 186(4), E150-E156. doi: 10.1503/cmaj.131155

Stones, M., Kozma, A., McNeil, K., \& Worobetz, S. (2011). Subjective well-being in later life: 20 years after the butterworths monograph series on individual and population aging. Canadian Journal on Aging, 30(3), 467-477. doi: 10.1016/S0140-6736(13)61489-0

Tamim, H., Mason, J., Shah, S., \& Dogra, S. (2012). Happiness is a determinant of physical activity levels among ethnically diverse older adults. Journal of Aging and Physical Activity, 20(5), S337.

World Health Organization. (2004). Promoting mental health: concepts, emerging evidence: summary report. Geneva, Switzerland: Author. Retrieved from www.who.int/mental_health/evidence/en/promoting_mhh.pdf 